CZU:577.218+616-098

https://doi.org/10.52692/1857-0011.2021.3-71.23

\title{
THE LINK BETWEEN CIRCADIAN CLOCK AND TUMORIGENESIS
}

\author{
${ }^{1}$ Arianna DANERI, \\ ${ }^{2,3}$ Adrian LUPUȘOR, \\ ${ }^{2,3}$ Ion MOLDOVANU, \\ ${ }^{2,3}$ Victor VOVC
}

\author{
${ }^{1}$ The University of Genoa.Scuola di Scienze Mediche e Farmaceutiche, Genoa, Italy \\ ${ }^{2}$ State University of Medicine and Pharmacy "Nicolae Testemitanu", Chisinau, MD, \\ ${ }^{3}$ Institute of Neurology and Neurosurgery, Chisinau, MD \\ email: adrian.lupusor@usmf.md
}

\section{Rezumat. Relația dintre ceasul circadian și tumorigenză}

Ritmul circadian este fundamental pentru a permite corpului uman să funcționeze corect. Studiile au demonstrat că perturbarea ritmului circadian este un factor de risc pentru un număr mare de stări patologice. Scopul aceastui articol este de a realiza o revistă a literaturei depre relația dintre influența tulburărilor de ritm circadian asupra tumorogenezei. Cancerul este o "ciumă" a societăţii de astăzi și este interesant de observat cum stilul de viaţă modern poate fi unul dintre cele mai importante motive pentru a explica răspândirea enormă a tumorilor. Punctul crucial descris este legătura dintre lumină, melatonină şi genele cancerului; această triadă are un rol important în tumorigeneză. După aceea, se pune accent pe cancerul de sân care este cel mai frecvent din lume și se demonstrează, de asemenea, modul în care nivelul social și educația pot influența posibilitatea de a dezvolta cancer în timpul vieții. În final, există o descriere a uneia dintre posibilele noi frontiere în tratamentul cancerului: cronoterapia.

Cuvinte cheie: ceas circadian, perturbare circadiană, lumină artificială, cancer - gene ceas, cancer mamar, cronoterapie.

\section{Summary. The link between circadian clock and tumorigenesis}

The circadian clock is fundamental for allowing the human body to work properly. Studies demonstrated that circadian disruption is a risk factor for a lot of pathological states and in this Review, the idea is to focus on tumorigenesis. Cancer is a social plague and it is interesting to note how the human lifestyle can be one of the most important reasons to explain the enormous spread of tumours. The crucial point described is the connection between light, melatonin and cancer genes; this triad has an important role in tumorigenesis. After that, there is a focus on breast cancer that is the most frequent in the world, and it is also demonstrated how social level and education can influence the possibility to develop cancer during life. In the end, there is a description of one of the possible new frontiers in the treatment of cancer: chronotherapy.

Key-words: : circadian clock, circadian disruption, artificial light, cancer - clock genes, breast cancer, chronotherapy.

\section{Резюме. Связь между циркадными часами и опухолеобразованием}

Циркадный ритм имеет фундаментальное значение для нормального функционирования человеческого организма. Исследования показали, что нарушение циркадного ритма является фактором риска многих патологических состояний. Целью данной статьи является обзор литературы, посвященной взаимосвязи между влиянием нарушений циркадного ритма и онкогенезом. Рак - это «чума» современного общества, и интересно отметить, как современный образ жизни может быть одной из самых важных причин, объясняющих огромное распространение опухолей. Описанный ключевой момент - это связь между светом, мелатонином и генами рака; эта триада играет важную роль в онкогенезе. После этого основное внимание уделяется раку груди, который является наиболее распространенным в мире, а также демонстрируется, как социальный статус и образование могут повлиять на возможность развития рака в течение жизни. Наконец, приведено описание одного из возможных новых рубежей в лечении рака: хронотерапии.

Ключевые слова: циркадные часы, нарушение циркадного ритма, искусственный свет, рак - часы гены, рак груди, хронотерапия.

\section{Introduction}

Human body homeostasis is dependent on Earth spin as it is exposed to the sunlight differently during a day, and as a result, the behaviours and physiological processes of the body are oscillatory and must be synchronised correctly. These oscillatory processes are orchestrated by a synchronization system (SS) or in other words the biological clock of the body. This watch has the function of coordinating and synchro- nizing all the physiological processes of the human body. SS it consists of the central clock, represented by the suprachiasmatic nucleus ( $\mathrm{SCN}$ ) of the hypothalamus and peripheral clocks represented by "clock genes" at the level of each cell. All living organisms possess this synchronization system that orchestrates each process and biological function, from the gene to the organ. As a result of the activity of this synchronization system, several types of processes are formed 
which are repeated with a certain regularity, forming different biological rhythms. The diversity of biological rhythms is great, varying between a few seconds and a few years. Among these the most studied is the circadian rhythm, which lasts about 24 hours. The circadian rhythm encompasses everything the resulting physiological and behavioural processes in an organism for a day. There are also infradian rhythms (cycles having a duration of more than 24 hours, for example, the menstrual cycle in women) and ultradian rhythms (cycles with a duration of less than 24 hours - breathing, heart contraction, processes food etc) (17).

At the same time, many studies demonstrated that circadian disruption is a risk factor for a lot of pathological states. Moreover, because cell division is related to the clock genes, circadian rhythm disorders are an important risk factor for tumorigenesis.

\section{Circadian clock}

The Circadian clock is a biochemical oscillator tied on 24 hours synchronised with solar time and for this reason, it is influenced by the environment, thanks to this the human body knows when it's time to sleep or to be awake $(1,2,3,4)$.

There is a central clock that is produced and maintained by the suprachiasmatic nucleus of the hypothalamus, which is considered a circadian pace- maker. There are also subordinate clocks in peripheral tissues (liver, kidney, skin, intestine, lung, pancreas, ovary and heart) synchronized through neural and humoral inputs including the autonomic nervous system and the neuroendocrine system $(3,4,5)$.

The release of hormones is connected with the circadian rhythm, as there are some biological oscillations. For example, during the night melatonin and prolactin increase, while cortisol has a peak in the early morning. Melatonin is a hormone that makes humans feel sleepy, Cortisol is the hormone of stress: this cycle helps humans maintain a routine in sleep habits $(2,14)$.

Melatonin is a natural hormone that is produced by the pineal gland in the brain. Light stops the production of the hormone, whereas darkness triggers its production $(2,14)$.

Body temperature and metabolism are also part of the human circadian rhythm. During the night the temperature drops and calories are used to restore damaged parts of the human body during the day and for immune responses. During the day the body temperature increases and calories have to be used for muscles and the neurological system $(2,4,5)$.

In summary, the most important functions regulated by circadian rhythm are the possibility to fall asleep, the regulation of wakefulness, body tempera-

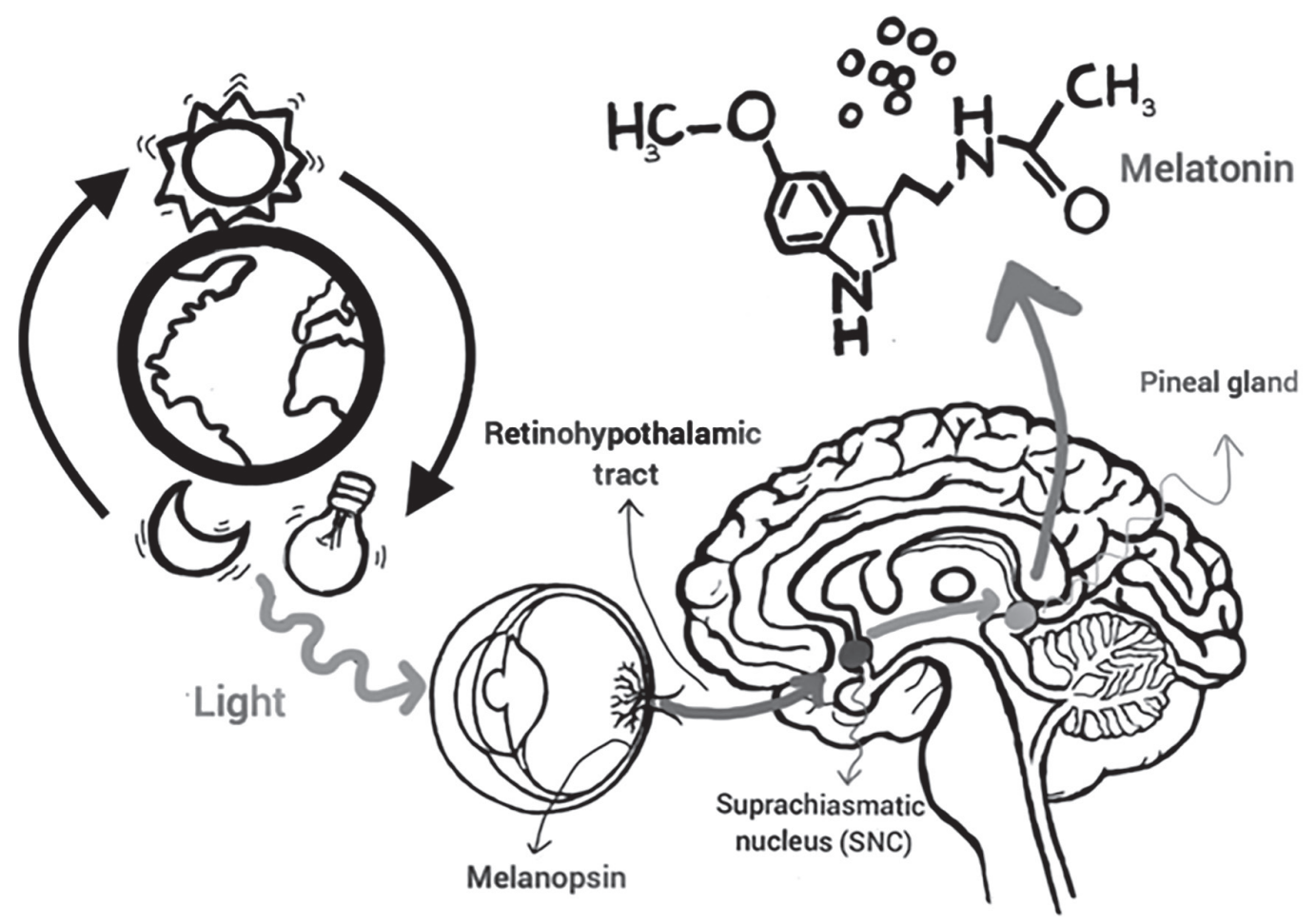

Figure 1. The Pathway of Melatonin Secretion

In this figure, there is a description of the mechanism which lead to the production of melatonin. Natural or artificial light is absorbed by the retina. Melanopsin is a photopigment found in a subtype of photoreceptive retinal ganglion cells which projects to the suprachiasmatic nucleus via the retinohypothalamic tract, in this way the information about the presence/absence of the light is sent to the central nervous system as a nervous signal. Melatonin is produced by the pineal gland and its production is triggered by darkness, while lightness stops it. 
ture, blood pressure, hormone biosynthesis, digestive secretion and immune responses $(2,4,5)$.

Light is the most important environmental factor that regulates the circadian rhythm. In the human body, there is a photoreceptors system that sends signals about darkness or lightness to the human brain (7). Melanopsin is a photopigment found in a subtype of photoreceptive retinal ganglion cells which projects to the central nervous system through the retinohypothalamic tract the information about the presence/absence of the light (Fig.1).

Some variables can generate differences in the regulation of the circadian clock between humans, for example, eye colour: people with dark eyes have more melanin that absorbs more light than people with pale eyes and this influences human behaviour (12).

Moreover, it is important to note that the circadian rhythm is different in children, adolescents and adults and this contrast is reflected in different sleep habits.

It is well known that the circadian clock controls also cellular physiology: cell division, metabolism, cells proliferation, response to DNA damage, apoptosis. The mitotic cell cycle has similarities with the circadian clock because of the presence of periodic phases of activation and repression. Normally most cell divisions occur in a specific part of the day and for this reason, the circadian clock influences also cell proliferation. This regulation has to be correct to prevent tumorigenesis. Apoptosis can be promoted or restricted according to the phase of the circadian clock. This physiological role of Circadian rhythm is crucial to explain how it can be part of tumorigenesis $(1,11)$.

\section{Circadian Disruption}

The circadian clock can be disrupted in many situations: unhealthy lifestyle as working shifts that do not respect the natural light and dark times of the day, jet lag, late-night hours, lack of sleep, eating or drinking late at night, watching screens too close to bedtime or not having a comfortable sleeping space. Pathogenic conditions as stress, mental health problems, brain damage, dementia, blindness and sleep disorders also can disrupt the circadian rhythm.

Moreover, circadian disruption can be the cause of pathogenic conditions as cancer, metabolic diseases like Cushing disease, cardiovascular diseases, diabetes, chronic inflammation, mental health conditions, depression and sleep disorders (3).

The most common sleep/wake alterations caused by circadian disruption are Delayed sleep phase syndrome, typified with tiredness in the morning and increasing alertness during the day; Advanced sleep phase syndrome that is the opposite with tiredness in the early evening; Free-running circadian disorders common in human without stability in a circadian pacemaker for example in the blind; irregular sleep/ wake syndrome usually occurring with neurological dysfunctions, schizoaffective disorders and psychomotor retardation. The symptoms are insomnia and excessive sleepiness during the day in association with irregular sleep. In these cases, the treatment is similar and it foresees a combination of pharmacological, light-related and behavioural strategies (15).

The circadian clock regulates metabolism, so an alteration in the circadian clock is inevitably reflected in metabolic dysregulation. In the same way, metabolic alterations can alter circadian oscillation, so it is important to follow a controlled feeding time to improve metabolic conditions. Cancer metabolism is predominantly based on glycolytic activity, despite aerobic conditions. This situation is called the Warburg effect and there is strong evidence that circadian disruption influences metabolic adaptations in favour of cancer development (1).

As it has already been said the most important environmental factor that can cause these alterations is light also in combination with alcohol, stress and irregular meals times (7). For example, if a person always eats at the same time, the body will be prepared for the meal and it will be possible to regulate each process involved in the digestion. In the same way, if a person does physical activity always at the same time human muscles will be prepared for that. So, it is important to have regular life and to try to find a repetitive lifestyle also for this reason.

Going back to talk about the light, the introduction of electricity light has inevitably changed and improved human life. Nowadays it is possible to have light to work at night, but also to enjoy it. Humans evolved without this possibility, so it is important to note that this invention will inevitably determine some changes in the human circadian rhythm. Light can increase alertness in humans, it decreases the production of melatonin and increases the production of cortisol. It is worth also pointing out that people have reduced their exposure to dark and the average duration of sleep has decreased; This change in the exposure to light plays a role in breast and prostate cancer, obesity and depression (7).

Even in utero, exposure to light can increase the risk to develop cancer in life, so it is also important to monitor women during pregnancy. For example, numerous publications have reported that in many leukaemia diagnosed children the origin of this specific cancer was from the intrauterine period of life $(7,16)$.

Light can increase the risk of cancer because of alterations in gene expression and alterations in the physiology of normal cells. This is due to the link between light and melatonin which has oncostatic 
functions including anti-proliferation, induction of apoptosis, inhibition of invasion and metastasis, anti-angiogenesis and enhancement of immunomodulation. Studies demonstrated that melatonin inhibition allows the growth of lung, breast, prostate, liver and colon cancer. Moreover, numerous publications have reported that melatonin can be an efficient treatment. It can improve the efficacy of chemotherapy and reduce side effects and most of all it can prolong survival time and enhance the quality of life (14).

\section{Circadian dysrhythmia and cancer}

Circadian disruption is a key factor in tumorigenesis, but at the same time, the presence of cancer can weaken the circadian rhythm (3). Anyway, loss of circadian control is an independent risk factor for cancer and it has been classified as a carcinogen. It is associated with early mortality and poor efficacy in the treatment (1).

At the molecular level everything is regulated by feedback circuits of a group of genes called "clock genes": CLOCK [Circadian locomotor output cycles kaput] the core transcription factor; BMAL1 [Aryl Hydrocarbon Receptor Nuclear Translocator-like protein 1] the core transcription factor, PER 1-2-3 [Period 1-2-3], Transcriptional repressor, CRY 1-2 [Cryptochrome 1-2] transcriptional repressor, REV-ERBalpha [Nuclear Receptor Subfamily 1, Group D, member 1(NR1D1)], a transcriptional repressor, ROR alpha [Retinoid-Related Orphan Receptor alpha], Transcriptional activator $(1,2,3,11)$.

CRY and PER form a transcriptional repressor complex to inhibit CLOCK/BMAL1 activity entering the nucleus. In this way, the clock is regulated by a negative feedback loop. There is also a secondary loop composed of REV-ERBalpha and RORalpha $(1,11,13)$.

The normal expression of Per1 and Per2 can suppress the proliferation in pancreatic cancer and inhibit breast cancer cell proliferation and tumour growth (for the second one is demonstrated only with Per1). Genetic or epigenetic alterations in the expression of these clock genes can be associated with specific cancer phenotypes (10). For example, Per1 and Per2 decreased expression levels can lead to sporadic and familial breast tumours; Perl lower expression levels can cause familiar breast tumours and undifferentiated colorectal tumours, while Per2 downregulation can increase breast cancer cell proliferation, tumour growth and the risk to develop colon cancer. Moreover, a lower expression rate of both (Per1 and Per2) is linked to Glioma and chronic myeloid leukaemia and the degradation of PER2 protein is linked to intestinal epithelial neoplastic transformation. Conversely, the increased expression of Per2 can cause tumour apoptosis in breast cancer and prostate cancer. In conclu- sion, the methylation of Per1 and Cryl's promoters allows to increase the survival of breast cancer cells and the proliferation (but in the proliferation, there is evidence only for Per) and the methylation of Per3 is linked to chronic myeloid leukaemia (2).

Studies demonstrate that CLOCK and BMAL1 are tumour suppressors. Clock genetic polymorphisms can enhance the risk of breast cancer and Clock single-nucleotide polymorphisms can determine ER/ PR-negative cases of breast cancer and in general, they are associated with an increased risk to develop prostate, breast, ovarian and pancreatic cancer. This is not always true because colorectal cancer is an exception: in this case CLOCK and BMAL1 expression is elevated and they increase its proliferation $(1,11)$.

CLOCK can inhibit apoptosis together with PER1. Publications have reported that the knockdown of PER1 determines a downregulation of antiapoptotic BCL-2 and upregulation of proapoptotic BAX in hepatocellular carcinoma cells, increasing apoptosis. (1)

Numerous publications have reported that an incorrect exposure to light can cause hypomethylation of the CLOCK promoter and it can lead to cancer, particularly breast cancer. For example, it is interesting to understand if shift work by a pregnant woman might have epigenetic consequences for her child that could increase the risk of cancer or even affect fetal growth and development (16).

In general, it is possible to understand that an alteration in the expression of these genes leads to develop cancer because their proliferation, apoptosis and migration are dysregulated $(1,11)$.

Circadian disruption can also interact with the tumour microenvironment which is fundamental for its development. Cancer cells are heterogeneous and they include cancer stem cells (CSCs), and an important feature is their niche. The niche protects CSCs from insults, which are the immune response, chemotherapy and genotoxic stresses. The primary niche is composed of extracellular matrix (ECM) and cancer-associated fibroblasts (CFAs). Circadian disruption can activate CFAs which produce ECM components, various cytokines and an autocrine growth factor WNT10a. This can help to maintain the niche required for CACs. In addition, to enable the process of metastasis, the presence of a metastatic niche is necessary, where the cancer cells can survive, colonise and expand to form the metastasis. An important piece of evidence is that collagen density promotes the onset and the progression of breast cancer (6).

\section{Epidemiology}

Nowadays, the incidence of cancer may continue to increase because of the human lifestyle. This happened due to various reasons, such as exposure to electric 
light, stress, shift work, continuous hormonal imbalances, which are all factors that can alter the circadian rhythm. The evidence is that the risk of breast and prostate cancer is higher in modern society $(2,5,6,7)$.

Reporting some data to understand the seriousness of the problem, in 2020 one out of five people developed cancer all over the world. This fact is reported in the article "Global cancer Statistics 2020", which analysed 36 tumours in 185 different countries. In 2020 there were 19.3 million cases and 10 million deaths, but it is worth pointing out that the COVID-19 pandemic could make the situation worse with increased cases and mortality (8).

The most frequent cancer in 2020 were: breast cancer $11,7 \%$ of diagnoses, lung cancer $11,4 \%$, colorectal cancer $10 \%$, prostate cancer $7,3 \%$, stomach cancer 5,6\% (8). Instead, mortality rates are slightly different: lung cancer $18 \%$ of all cancer deaths, colorectal cancer 9,4\% and hepatic cancer 8,3\% (8).

\section{Breast cancer}

Breast cancer is the most common in the world. Genetic alterations have been found only in less than $10 \%$ of cases. The majority is linked with non-hereditary-causes: alcohol consumptions, nutrition-related factors, exogenous hormones intake, night work, work shifts duration, reproductive history, menstruation parameters, hormonal receptor status, mostly in premenopausal women, environmental factors, air pollution and of course altered light/dark cycles (9).

Circadian disruption can act on stemness and increase the cancer-cell dissemination and the process of metastasis; moreover, it can create an immunosuppressive shift in the tumour microenvironment (9).

Shift work and night-time work are considered carcinogens because of the alterations caused in the circadian rhythm (10). The shift-work disorder can be considered as a chronic version of jet lag which has a major impact on human health (13).

Studies showed that employment in jobs with unpredictable shifts depends on socioeconomic status and gender but it is more common among people with lower levels of education. This situation causes higher mortality rates in cancer breast, but of course not only in this one. In the United States, a study demonstrates that black women are $40 \%$ more likely to die of breast cancer than white women (10).

The mechanism is always the same, shift work and night-time work alter the rhythmicity of the circadian clock and reduce melatonin which has anti-metastatic and anti-tumour functions. This situation leads to increased production of estrogens and an alteration in the function of estrogen receptors (10).

Moreover, publications have reported that Circadian Disruption allows a shift of the tumour immune mi- croenvironment, most of all because of the alterations in CXCL5 and CXCR2. In particular CXCR2 signalling plays a role in the modulation of the tumour immune microenvironment and the construction of the pre-metastatic niche, because of the employment of Myeloid-derived suppressor cells (MDSCs) in distant metastatic sites. In general, CXCL5-CXCR2 axis is associated with the process that allows cancer cells to circulate in the blood and to reach the bones most of all (9).

There is another key mechanism that permits the process of metastasis: CXCL12-CXCR4 axis. In conclusion, it is possible to assert that there is a strong link between circadian disruption and cancer-cell dissemination; studies promote the use of CXCR2 or CXCR4 inhibitors in combination with chemotherapy and possibly immunotherapy allow to overcome resistance (9).

In conclusion, as we have already mentioned, circadian disruption can alter the release of cortisol and the studies demonstrated that an abnormal diurnal salivary cortisol rhythm in patients with metastatic breast cancer is linked with a doubling of the risk of death as compared with people with a normal pattern; so this is further evidence of how circadian rhythm is connected with tumorigenesis. Moreover, it is demonstrated that an alteration in rest-activity in patients with metastatic colorectal cancer is connected with a low chance of survival (5).

\section{Chronochemotherapy}

The new frontier in the treatment of cancer is circadian-timed cancer treatment. The aim is to maximise the anti-tumour effects of cancer and minimise toxicity and side effects considering the human body's natural rhythms in the treatment of an illness (1). The efficacy of a drug, its pharmacokinetics, metabolism and toxicity may vary with circadian phases and time of the day. Chronotherapy has been applied also to treat asthma, hypertension, cardiovascular diseases. Unfortunately, studies have not produced enough positive results to justify this healing attempt. For example, in the treatment of colorectal cancer, there were no beneficial effects. Furthermore, this treatment can be dangerous for a part of the population, depending on age and gender.

The research aims are to understand the best time to kill tumour cells. This is a hard challenge because it is known that the circadian rhythm of cancer cells can be rhythmic, but also out of phase with normal tissue. It is common knowledge that human cells repair is lower in the morning and higher in the evening and during the night, but we cannot tell the same thing about cancer cells (13).

\section{Conclusion}

In the modern era, it is considered normal the lack of free time and over usage of digital devices, to be stressed and at the same time sleepy, to abuse coffee 
or tea, to be sleep deprived or to not respect sleep consistency. Also, people are travelling a lot changing the time zone. The most important dangerous factor is the spread of artificial light which can alter the production of melatonin with all the consequences. All these factors are disrupting the circadian rhythm which has a fundamental function for the homeostasis and well-being of the human body. In our society is considered normal this way of living, maybe it would be better to declare that we are almost obliged to have it.

In addition, the risk to develop cancer is increasing and this is inevitably linked to the modern human lifestyle that does not respect the natural light and dark times of the day along with too much stress during evening and night, food, alcohol, smoke and gadgets. It is necessary to decrease this pathological cycle, but at the same time human society is inevitably going to change very quickly, so we need to figure out how this new way of living will affect human health in the future.

Further studies are necessary to attempt a better understanding of how circadian rhythm disruption influences tumour development. In this way, it will be possible to increase the awareness of people about this relationship and at the same time to develop new methods of prevention and treatment of cancer.

Contribuție: Finanțarea publicației în cadrul proiectului 20.80009.8007.01

\section{References}

1. Ayesha A. Shafi et al. Cancer and the Circadian Clock. Cancer Res., (2019), 79:3806-3814.

2. Christos Savvidis et al. Circadian Rhythm Disruption in Cancer Biology. MOL MED, (2012) 18:1249-1260.

3. Anton Shostak et al. Circadian Clock, Cell Division, and Cancer: From Molecules to Organism., (2017) Int. J. Mol. Sci. 18, 873.

4. Matúśs Soták et al. Cross-talk between the circadian clock and the cell cycle in cancer. Annals of Medicine, (2014); 46: 221-232.
5. Elisabeth Filipski et al. Circadian Disruption in Experimental Cancer Processes. Integrative Cancer Therapies, (2009), 8(4) 298-302.

6. Hiroto Izumi et al. Circadian disruption and cancer risk: A new concept of stromal niche. International Journal Of Oncology, (2014) 44: 364-370.

7. Richard G. Stevens et al. Meeting Report: The Role of Environmental Lighting and Circadian Disruption in Cancer and Other Diseases. Environ Health Perspect, (2007) 115:1357-1362.

8. Hyuna Sung et al. Global Cancer Statistics 2020: GLOBOCAN Estimates EF incidence and Mortality Worldwide for 36 Cancers in 185 Countries. CA CANCER J CLIN; 7, (2021)1:209-249.

9. Eva Hadadi et al. Chronic circadian disruption modulates breast cancer stemness and immune microenvironment to drive metastasis in mice. Nature communication., (2020), 11:3193.

10. Sarah Gehlert et al. Shift work and breast cancer. Int. J. Environ. Res. Public Health, (2020), 17, 9544.

11. Richard G.Stevens et al. Circadian disruption and breast cancer from Melatonin to Clock genes. Epidemiology; (2020), 16: 254-258.

12. Meyomo G. Wendeu-Foyet et al. Circadian Disruption and Prostate Cancer Risk: An Updated Review of Epidemiological Evidences. Cancer Epidemiol Biomarkers Prev; (2017), 26(7)

13. Aziz Sancar et al. Clocks, cancer, and chronochemotherapy. Science (2021), 371, 42

14. Zhiqiang Ma et al. Melatonin as a potential anticarcinogen for non-small-cell lung cancer. Oncotarget. (2016), 7(29): 46768-46784

15. Anita K. Simonds et al. ERS handbook. Respiratory Sleep medicine. European Respiratory Society, (2012)

16. Richard G. Stevens et al. Does Electric Light Stimulate Cancer Development in Children? Cancer Epidemiol Biomarkers Prev; , (2012), 21(5)

17. Lupușor Adrian, Spînu Doina, Odobescu Stela, Victor Vovc, Moldovanu Ion. Ritm circadian, melatonină, somn, durere, cefalee - relații și importanța clinică. Sinteză. Buletinul AȘM. (2020), 3(67): 57-65. 